\title{
MODEL REVITALISASI SEKOLAH TERDAMPAK ERUPSI MERAPI MELALUI PEMBUATAN PERANGKAT PEMBELAJARAN INOVATIF BERBAHAN DASAR LIMBAH ANORGANIK
}

\author{
Eko Widodo, Asri Widowati, dan Suyoso \\ FMIPA Universitas Negeri Yogyakarta \\ email: ekowidodouny@gmail.com
}

\begin{abstract}
Abstrak: Penelitian ini bertujuan untuk mengoptimalkan potensi lokal baik sumber daya manusia maupun material sisa bencana untuk merevitalisasi sekolah terdampak bencana Merapi. Metode penelitian yang digunakan adalah Research and Development menggunakan lima fase perancangan pengajaran model spiral diadaptasi dari 'five phases of instructional design' dari Cennamo dan Kalk (2005:6). Kelima fase tersebut adalah: definisi, desain, peragaan, pengembangan, dan penyajian. Proses dimulai dari definisi menuju kearah fase desain, peragaan, pengembangan, dan penyajian secara spiral melibatkan calon pengguna, ahli materi, anggota tim instruktur, dan pebelajar. Hasil penelitian menunjukkan: (1) terjadi peningkatan keterampilan masyarakat dalam memanfaatkan limbah anorganik untuk membuat perangkat pembelajaran sains realistik, ditandai kemampuan menerjemahkan desain; (2) Respon guru dan siswa sangat baik (kategori rata-rata 4,3 dari skala 5) terhadap perangkat pembelajaran; dan (3) revitalisasi sekolah ditunjukkan dengan tersedianya perangkat pembelajaran sains yang dihasilkan masayarakat sehingga terjalin kemitraan yang kolaboratif.
\end{abstract}

Kata Kunci: Perangkat pembelajaran inovatif, model revitalisasi sekolah, limbah anorganik

\section{THE REVITALIZATION MODEL OF THE SCHOOLS AFFECTED BY MERAPI ERUPTION THROUGH THE INNOVATIVE TEACHING KIT DEVELOPMENT USING ANORGANIK WASTE AS THE PRIMARY MATERIALS}

\begin{abstract}
Abstrak: This study was aimed to optimize the local potential both in the form of human resources and materials resulted from the disaster to revitalize the schools affected by Merapi eruption. The method used was the research and development method using the five phases of the spiral model teaching design adapted from 'Five phases of instructional design' by Cennamo and Kalk (2005:6). The five phases were definition, design, display, development, and presentation. The process started with the definition to the phase of design, display, development, and presentation involving the potential users, materials experts, instructor team members, and learners. The findings showed: (1) there was an improvement of the community's skill in utilizing the anorganic waste to develop realistic science teaching kits. This could be seen from the ability to understand the design; (2) there was a very good response from the teacher and the students (with a mean of 4.3 out of the 5 scale) on the teaching kits; and (3) the school revitalization was indicated by the availability of the science teaching kits produced by the community so that a collaborative cooperation was established.
\end{abstract}

Keywords: innovative teaching kits, school revitalization model, anorganic waste

\section{PENDAHULUAN}

Hampir seluruh wilayah di Indonesia, sesuai dengan kondisi geografisnya, termasuk daerah yang rawan bencana alam. Dalam banyak peristiwa bencana, kondisi darurat pascabencana biasanya berlangsung dalam waktu lama. Situasi ini jelas kurang menguntungkan bagi anak-anak yang harus belajar dengan fasilitas yang serba terbatas, yang pada akhirnya proses belajar mengajar tidak bisa berlangsung secara optimal. Anak-anak adalah salah satu kelompok rentan yang paling berisiko terkena bencana. Dalam berbagai peristiwa bencana yang terjadi di seluruh belahan bumi, banyak anak-anak yang menjadi korban, baik luka-luka maupun meninggal.

Bencana juga sering menimbulkan dampak berkepanjangan bagi anak-anak. Hancurnya 
infrastruktur pendidikan akibat bencana vulkanik merapi di Yogyakarta, September 2010, misalnya, telah menyebabkan ribuan anak sekolah kehilangan kesempatan untuk mengikuti kegiatan pendidikan dalam jangka waktu cukup panjang. Data dari Kemendiknas dan Disdikpora DIY Berdasarkan data hasil koordinasi dengan Dinas Pendidikan Provinsi DIY terdapat 33.262 siswa dan 2.989 guru yang mengungsi. Sementara itu, dari 226 sekolah yang terkena dampak bencana Merapi sebanyak 40 sekolah rusak, 274 ruang rusak, dan 186 sekolah yang harus dibersihkan.Adapun jumlah siswa yang mengungsi dari empat kabupaten di Provinsi Jawa Tengah sebanyak 20.640 orang. Jumlah sekolah rusak sebanyak 35 sekolah, ruang rusak 1 (SMK), dan 491 sekolah yang harus dibersihkan (Djajadiningat, 2008).

Bencana besar ini telah melumpuhkan infrastuktur dan meninggalkan trauma yang sangat berat, terutama pada anak-anak yang seharusnya memperoleh hak atas pendidikan. Dengan kondisi tersebut, metode pembelajaran yang ada tidak dapat diterapkan pada kondisi di daerah bencana, terlebih lagi kita belum memiliki media pembelajaran yang dapat diterapkan pada kondisi pascabencana baik karena bencana alam maupun konflik. Jikapun ada, namun belum tersosialisasikan dengan baik. Oleh karena itu perlu adanya upaya pengembangan alat-alat praktikum yang dapat berfungsi sebagai media trauma healing dari re-use limbah anorganik melalui kegiatan pemberdayaan dan kemitraan dengan masyarakat sekitar sekolah. Penelitian ini dapat menjadi model penanganan pendidikan di sekolah pasca bencana, mengingat Indonesia termasuk pada wilayah yang rawan bencana.

Untuk itulah, dipandang sangat perlu untuk mempersiapkan perangkat pembelajaran yang dapat berfungsi sebagai media trauma healing sebagai salah satu upaya akselerasi pemulihan pembelajaran dan rehabilitasi kondisi psikologis siswa. Mengingat kondisi darurat dimana banyak alat pembelajaran yang rusak maka dibuat media pembelajaran relistik dari hasil re-use limbah anorganik (misal, plastik dan logam) yang khusus diimplementasikan untuk penanganan pendidikan di daerah pasca bencana. Penelitian ini sekaligus untuk mengenalkan pada siswa tentang pengetahuan-pengetahuan tentang masalah kebencanaan, sebagaimana ditekankan oleh United Nations International Strategy for Disaster Reduction (UN ISDR) dalam bentuk Institutionalizing Integrated Disaster Risk Management At School.

Tujuan penelitian ini adalah mengoptimalkan potensi lokal baik sumber daya manusia maupun bahan alam atau material sisa bencana yang tersisa untuk merevitalisasi sekolah yang terdampak bencana Merapi, yang dilakukan dengan cara sebagai berikut.

- Mengembangkan pemberdayaan dan kemitraan dengan masyarakat wilayah lereng Merapi dalam pembuatan perangkat pembelajaran dengan memanfaatkan limbah anorganik seperti plastik dan logam yang mudah di dapat di daerah pasca bencana.

- Mendesain strategi belajar mengajar dengan pendekatan trauma healing, dalam upaya meningkatkan ketahanan mental dan motivasi belajar siswa pasca bencana Merapi

- Mengembangkan pembelajaran tentang deteksi dini dan resiko kebencanaan yang diintegrasikan dalam mata pelajaran sains secara tematik.

- Mengembangkan Subject Special Pedagogy (SSP) berbasis trauma healing dengan memanfaatkan media dari limbah anorganik seperti plastik dan logam.

- Mengembangkan model evaluasi proses dan produk pembelajaran sains untuk siswa sekolah dasar dan menengah pascabencana Merapi.

Karena penelitian ini bertujuan untuk mengembangkan perangkat pembelajaran melalui pemberdayaan dan kemitraan dengan masyarakat yang sekaligus dilengkapi dengan strategi pembelajaran yang didesain khusus dengan pendekatan trauma healing untuk dilaksanakan di sekolah darurat di daerah bencana, jelas sangat penting baik secara teoretis maupun praktis untuk membantu berlangsungnya proses belajar-mengajar di daerah yang mengalami bencana, maupun secara teoretis untuk menghasilkan perangkat pembelajaran yang dapat diadap- 
tasi di berbagai daerah bencana. Beberapa hasil lain dari penelitian ini adalah sebagai berikut.

- Secara teoretis pembuatan perangkat pembelajaran melaui pemberdayaan masyarakat untuk pembelajaran sekolah darurat dengan pendekatan trauma healing dapat dijadikan acuan untuk diterapkan baik di Perguruan Tinggi untuk mengembangkan pengabdian dan penelitian maupun di sekolah-sekolah pasca terjadinya bencana.

- Produk alat-alat pembelajaran yang dihasilkan dapat digunakan untuk pembelajaran sains bagi pendekatan trauma healing, baik yang secara khusus di daerah bencana maupun yang dapat digunakan secara umum.

- Pengembangan strategi pembelajaran dapat dijadikan rujukan bagi guru-guru yang menangani siswa di sekolah darurat.

- Model, LKS, dan pedoman kegiatan belajar lainnya dapat digunakan secara di sekolah yang membutuhkan.

- Peneliti dapat melakukan identifikasi mengenai kelayakan peralatan dan perangkat pembelajaran lainnya untuk dikembangkan lebih lanjut.

\section{METODE}

Terkait dengan penelitian mengenai model trauma healing di sekolah terdampak bencana ini, salah satu alternatif metode yang tepat digunakan adalah research and development. Gay (1990) mengemukakan bahwa pendekatan research and development digunakan dalam situasi yang dapat dijelaskan sebagai berikut. Tujuan utamanya tidak untuk menguji teori, tetapi untuk mengembangkan dan memvalidasi perangkat-perangkat yang digunakan di sekolah agar bekerja dengan efektif dan siap pakai. Produk-produk tersebut dikembangkan untuk memenuhi kebutuhan dan berdasarkan spesifikasi yang ditentukan. Reseach and development menghasilkan produk-produk yang telah diuji dilapangan dan telah direvisi pada tingkat keefektifan tertentu.

Beranjak dari pertimbangan pendekatan sistem bahwa pengembangan asesmen tidak akan terlepas dari konteks pengelolaan maupun pengorganisasian belajar, dipilih model spiral sebagaimana yang direferensikan oleh Cennamo dan Kalk (2005:6). Dalam model spiral ini dikenal lima fase pengembangan yakni: definisi (define), desain (design), peragaan (demonstrate), pengembangan (develop), dan penyajian (deliver).

Kegiatan pengembangan dimulai dari fase definisi (yang merupakan titik awal kegiatan), menuju keluar kearah fase-fase desain, peragaan, pengembangan, dan penyajian yang dalam prosesnya berlangsung secara spiral dan melibatkan pihak-pihak calon pengguna, ahli dari bidang yang dikembangkan (subject matter experts), anggota tim dan instruktur, dan subjek belajar. Pada setiap fase pengembangan selalu diperhatikan unsur-unsur pembelajaran yakni outcomes, aktivitas, pebelajar, asesmen dan evaluasi. Proses pengembangan akan berlangsung mengikuti gerak secara siklus iterative (iterative cycles) dari visi definisi yang samar menuju ke arah produk yang teruji efektivitasnya. Hal itu sesuai dengan yang direferensikan oleh Dorsey, Goodrum, \& Schwen, 1997 (Cennamo \& Kalk, 2005:7) yang dikenal dengan "the rapid prototyping process".

Metode penelitian dan pengembangan ini adalah deskriptif, evaluatif, dan eksperimental. Metode penelitian deskriftif digunakan dalam penelitian awal untuk menghimpun data tentang kondisi yang ada. Metode penelitian evaluatif digunakan untuk mengevaluasi proses uji coba pengembangan suatu produk. Metode penelitian eksperimen digunakan untuk menguji keampuhan dari produk yang dihasilkan. Pada tahap pengujian lapangan, dilakukan strategi collaboration action research yang melibatkan mahasiswa menggunakan perangkat pembelajaran inovatif untuk trauma healing oleh mahasiswa KKN-PPL di sekolah yang rawan bencana di Kecamatan Cangkringan.

Penelitian dimulai dengan melakukan analisis kebutuhan di sekolah yang berpotensi terkena bencana baik akibat bencana vulkanik Gunung Merapi maupun akibat bencana gempa tektonik. Analisis dilakukan untuk mengetahui kebutuhan mendasar terkait dengan keberlangsungan proses belajar mengajar dalam upaya 


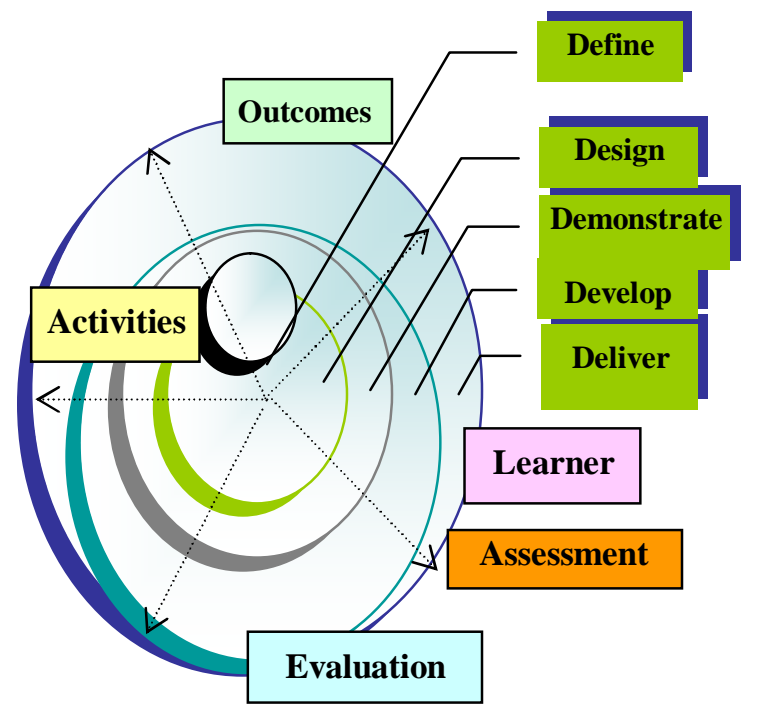

Gambar 1. Lima Fase Perancangan Pengajaran Model Spiral Diadaptasi dari 'Five Phases of Instructional Design' dari Cennamo dan Kalk (2005:6)

trauma healing pasca terjadinya bencana. Secara sederhana tahapan penelitian yang telah berhasil dilakukan pada penelitian tahun pertama ini dapat dilihat pada uraian di bawah ini.

Selanjutnya, hasil pengembangan dicobakan melalui penelitian tindakan kelas. Hasil penelitian tindakan kelas dikelompokkan kedalam dua aspek, yaitu keberhasilan proses dan keberhasilan produk. Evaluasi juga dilakukan melalui test untuk mengukur peningkatan kognitifnya. Hasil tes lalu diuji dengan uji beda (uji-t). Dalam pelaksanaan penelitian, jika ada kekurangan dalam evaluasi dan monitoring diadakan cek dan recek melalui, diskusi, catatan evaluator, dan melalui pengamatan lewat hasil rekaman video. Tugas evaluator dan kolaborator mengamati jalannya kegiatan pembelajaran, baik pada proses pembelajaran teori maupun praktik, terutama kegiatan magangnya. Selain itu, juga dilakukan pengamatan situasi, lokasi, jumlah siswa yang hadir, lamanya pembelajaran, sikap peneliti (dosen), sikap siswa, repon mahasiswa KKN-PPL dan siswa dalam memberikan alternatif terhadap permasalahan yang timbul (Kem, Morisson, \& Stevan, 2004).

\section{HASIL DAN PEMBAHASAN}

Penelitian ini menghasilkan sebuah model pembelajaran berbasis pemanfaatan media trauma healing untuk menyelesaikan beberapa akar permasalahan yang berkaitan dengan pemerataan akses pendidikan, khususnya bagi masyarakat yang terdampak bencana Merapi.

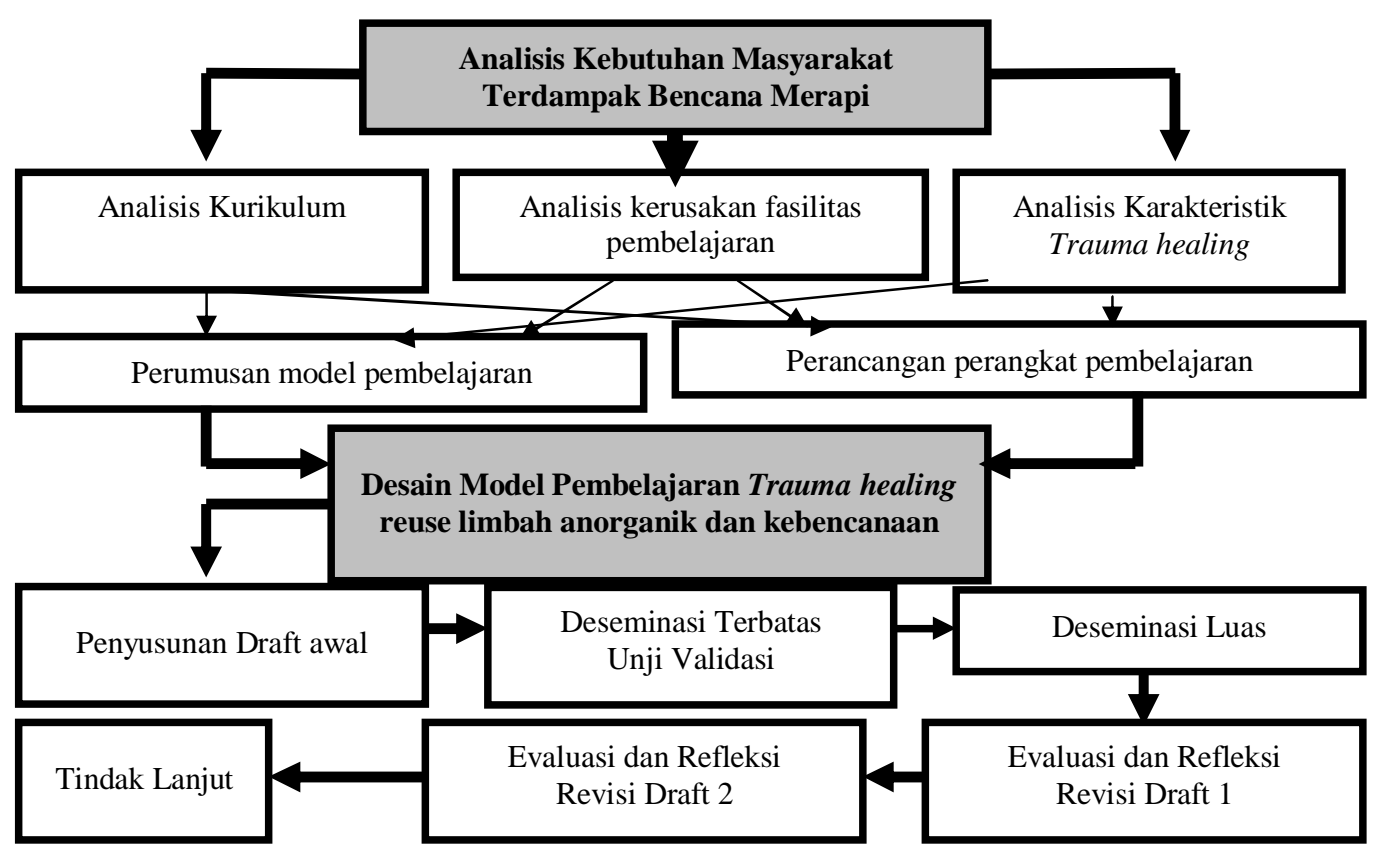

Gambar 2. Diagram Alir Rancangan Pengembangan Model Pemberdayaan Masyarakat dalam Pembuatan Perangkat Pembelajaran Inovatif dengan Pendekatan Trauma Healing untuk Rehabilitasi Psikologis Siswa di Daerah Terdampak Merapi 
Pertama, rusaknya fasilitas pendidikan sehingga penelitian ini berupaya memaksimalkan peranan masyarakat lokal untuk membantu sekolah yang terdampak bencana. Kedua, melatih siswa untuk terbiasa menerapkan pengetahuannya untuk menyelesaikan masalah-masalah aktual dan kontekstual yang ada disekitarnya. Hal ini penting karena setiap tahun bencana yang terjadi menimbulkan rusaknya fasilitas pendidikan dan terganggunya pembelajaran. Perangkat pembelajaran dari bahan limbah anorganik sebagai media trauma healing ini sangat penting karena dua hal pokok, yaitu pemanfaatan limba anorganik menjadi barang berguna dan berharga bagi pendidikan, dan yang kedua penyelesaian masalah pembangunan khususnya kesempatan belajar bagi masyarakat terdampak bencana (Murtado, Djuli, Said, 2008). Ketiga, memasukan sebuah strategi pemberdayaan masyarakat dalam mengantisipasi resiko bencana. Keempat, mempersiapkan sebuah model trauma healing melalui pembelajaran sains lengkap dengan perangkat pembelajaran yang dibuat dengan memanfaatkan reuse limbah anorganik. Kelima, dapat mengembangkan skill siswa yang sesuai dengan kebutuhan masyarakat sekitarnya. Kondisi geografis Indonesia yang rawan bencana, menyebabkan diperlukan kesiapsiagaan (disaster preperedness), termasuk dalam bidang pendidikan.

Hasil penelitian ini sebagai berikut. (1) Penelitian ini akan memberikan manfaat yang sangat berharga berupa pengalaman praktis dalam bidang ilmu pengetahuan dan teknologi. (2) Mahasiswa yang dilibatkan dalam penelitian diharapkan hasil penelitian ini dapat dijadikan bahan untuk mengembangkan pembelajaran tematik berbasis penanganan bencana sehingga dapat output dan outcome-nya jelas mengarah pada terbentuknya calon pendidik profesional yang peduli lingkungan. (3) Peneliti yang berminat dalam bidang Pemberdayaan Sumber Daya Masyarakat, apa yang menjadi kekurangan penelitian dapat disempurnakan dan dikembangkan pada penelitian selanjutnya. (4) Mem- berikan sumbangan bagi dunia ilmu pengetahuan dan teknologi serta untuk memperkaya khasanah (kebaikan) khususnya dalam bidang Pemberdayaan Sumber Daya Masyarakat.

Penelitian ini bertujuan untuk mengembangkan perangkat pembelajaran melalui pemberdayaan dan kemitraan dengan masyarakat yang sekaligus dilengkapi dengan strategi pembelajaran yang di disain khusus dengan pendekatan trauma healing untuk dilaksanakan di sekolah darurat di daerah bencana, maka jelas penting baik secara teoretis maupun praktis untuk membantu berlangsungnya proses belajarmengajar di daerah yang mengalami bencana, maupun secara teoretis untuk menghasilkan perangkat pembelajaran yang dapat diadaptasi di berbagai daerah bencana. Beberapa hasil lain dari penelitian ini adalah sebagai berikut.

- Secara teoretis pembuatan perangkat pembelajaran melaui pemberdayaan masyarakat untuk pembelajaran sekolah darurat dengan pendekatan trauma healing dapat dijadikan acuan untuk diterapkan, baik di perguruan tinggi untuk mengembangkan pengabdian dan penelitian maupun di sekolah-sekolah pasca terjadinya bencana.

- Produk alat-alat pembelajaran yang dihasilkan dapat digunakan untuk pembelajaran sains bagi pendekatan trauma healing, baik yang secara khusus di daerah bencana maupun secara umum.

- Pengembangan strategi pembelajaran dapat dijadikan rujukan bagi guru-guru yang menangani siswa di sekolah darurat.

- Model, LKS, dan pedoman kegiatan belajar lainnya dapat digunakan di sekolah yang membutuhkan.

- Peneliti dapat melakukan identifikasi mengenai kelayakan peralatan dan perangkat pembelajaran lainnya untuk dikembangkan lebih lanjut.

Kegiatan dipantau menggunakan performance assessment (kinerja peserta pelatihan masyarakat terdampak erupsi Merapi dan guruguru sains) sebagaimana terlihat pada Tabel 1. 
Tabel 1. Penilaian Kinerja Pelatihan Masyarakat Terdampak Erupsi Merapi

\begin{tabular}{llccccc}
\hline \multirow{2}{*}{ No. } & \multicolumn{1}{c}{ Apek yang Diamati } & \multicolumn{4}{c}{ Skala Pengamatan } \\
\cline { 3 - 6 } & & $\mathbf{1}$ & $\mathbf{2}$ & $\mathbf{3}$ & $\mathbf{4}$ & $\mathbf{5}$ \\
\hline 1. & Kehadiran dalam kegiatan pelatihan & $0 \%$ & $24 \%$ & $36 \%$ & $36 \%$ & $4 \%$ \\
2. & Kecermatan dalam membuat alat-alat peraga pembelajaran & $0 \%$ & $4 \%$ & $46 \%$ & $44 \%$ & $0 \%$ \\
3. & Kerjasama dengan sesama peserta pelatihan & $0 \%$ & $8 \%$ & $44 \%$ & $48 \%$ & $0 \%$ \\
4. & Keterlibatan dalam diskusi & $0 \%$ & $4 \%$ & $46 \%$ & $44 \%$ & $0 \%$ \\
5. & Keterlibatan dalam kegiatan pembuatan alat & $0 \%$ & $24 \%$ & $36 \%$ & $36 \%$ & $4 \%$ \\
6. & Kemampuan mengambil keputusan atau inisiatif & $0 \%$ & $2 \%$ & $48 \%$ & $44 \%$ & $0 \%$ \\
7. & Ide-ide baru & $0 \%$ & $28 \%$ & $12 \%$ & $44 \%$ & $4 \%$ \\
8. & Kemampuan komunikasi dengan sesama peserta & $0 \%$ & $16 \%$ & $44 \%$ & $28 \%$ & $4 \%$ \\
9. & Ketertarikan terhadap materi pelatihan & $0 \%$ & $4 \%$ & $44 \%$ & $36 \%$ & $8 \%$ \\
10. & Kemampuan menyelesaikan tugas-tugas pelatihan & $0 \%$ & $24 \%$ & $36 \%$ & $36 \%$ & $4 \%$ \\
11. & Kualitas hasil atau produk yang dibuat dalam pelatihan & $0 \%$ & $8 \%$ & $40 \%$ & $36 \%$ & $8 \%$ \\
12. & Kemampuan menjelaskan hasi atau prduk pelatihan yang & $0 \%$ & $8 \%$ & $42 \%$ & $44 \%$ & $0 \%$ \\
& dibuat & & & & & \\
\hline
\end{tabular}

Tabel 2. Pengelolaan KBM dalam Implementasi Perangkat Pembelajaran

\begin{tabular}{|c|c|c|c|c|c|c|c|c|c|}
\hline \multirow[t]{2}{*}{ No. } & \multirow{2}{*}{$\begin{array}{c}\text { Aspek yang Di- } \\
\text { amati }\end{array}$} & \multicolumn{6}{|c|}{ Skor Pengamatan tiap Pertemuan } & \multirow{2}{*}{$\begin{array}{c}\text { Skor } \\
\text { Rata- } \\
\text { rata }\end{array}$} & \multirow[t]{2}{*}{ Nilai Kategori } \\
\hline & & P1 & P2 & P3 & P4 & P5 & .. & & \\
\hline 1. & Persiapan & 3.25 & 3.5 & 3.25 & 3.5 & 3.25 & & 3.35 & Cukup \\
\hline 2. & Pendahuluan & 3.5 & 3.5 & 3.5 & 3.5 & 3.5 & & 3.5 & Baik \\
\hline 3. & Kegiatan Inti & 3.25 & 3.75 & 3.50 & 3.5 & 3.5 & & 3.5 & Baik \\
\hline 4. & Penutup & 3.75 & 3.5 & 3.25 & 4.0 & 3.75 & & 3.65 & Baik \\
\hline 5. & $\begin{array}{l}\text { Pengelolaan } \\
\text { waktu }\end{array}$ & 3.25 & 3.5 & 3.25 & 3.5 & 3.25 & & 3.35 & Cukup \\
\hline \multirow[t]{3}{*}{6.} & Suasana kelas & 3.5 & 4.0 & 3.5 & 3.75 & 3.5 & & 3.65 & Baik \\
\hline & Rata-rata & 3,42 & 3.63 & 3.38 & 3.63 & 3.46 & & 3.5 & Baik \\
\hline & Nilai Ketgori & cukup & baik & cukup & baik & cukup & & baik & \\
\hline
\end{tabular}

Pelaksanaan penelitian penerapan perangkat pembelajaran pada mata pelajaran sains dilaksanakan pada 18 sekolah mitra yang gurunya mengikuti pelatihan. Kegiatan implementasi telah dilakukan dengan durasi 2 kali pertemuan setiap minggu. Setiap kali tatap muka atau penyampaian satu RPP dilakukan pengamatan terhadap (1) kemampuan guru dalam mengelola KBM dengan instrumen evaluasi kompetensi guru; (2) aktivitas guru dan murid dalam pembelajaran; (3) profil kemampuan siswa; dan (4) kinerja dan sikap siswa dalam pembelajaran siswa selama KBM dengan instrumen yang bersesuaian. Hasil observasi masing-masing aktivitas tersebut disajikan di bawah ini.

Kemampuan guru mitra dalam mengelola pembelajaran kooperatif difokuskan pada ke- mampuan dalam kegiatan: persiapan pembelajaran, pendahuluan, kegiatan inti, penutup, pengelolaan waktu, dan kemampuan guru dalam mengendalikan suasana kelas. Hasil penilaian rata-rata dalam pengelolaan kegiatan belajar mengajar secara ringkas disajikan pada Tabel 2.

Kemampuan guru dalam mengimplementasikan rancangan pembelajaran dan perangkat yang dibuat masih ada yang nilainya di bawah 3.5 (cukup). Hal ini tentu saja akan mempengaruhi keberhasilan implementasi dari keseluruhan program penelitian yang dilakukan.

Aktivitas guru yang dominan adalah menjelaskan materi pembelajaran, yaitu 35,5\% dan mengusahakan contoh tambahan $21,5 \%$. Aktivitas guru yang paling sedikit adalah memberikan umpan balik $8 \%$ dan merangsang untuk 
mengingat konsep 8,5\%. Aktivitas siswa didominasi oleh kegiatan memperhatikan penjelasan guru atau siswa yang lain $32,1 \%$ dan yang paling sedikit adalah mengajukan pertanyaan $11,4 \%$ dan menuliskan hal yang penting $12,4 \%$.

Hasil tersebut sejalan dengan temuan Drajat (2011) yang telah menyelidiki arti penting pendidikan mitigasi bencana terhadap upaya pengurangan bencana bahwa upaya tersebut dapat ditempuh melalui beberapa hal berikut.

- Wajib dilakukan melalui pendidikan formal dalam program Sistem Pendidikan Nasional (Diknas) dengan desain kurikulum dari Badan Standarisasi Nasional Pendidikan (BSNP).

- Untuk jalur pendidikan informal melalui Badan Nasional Penanggulangan Bencana (BNPB) bekerja sama dengan instansi terkait, misalnya Kementerian Dalam Negeri, Kementerian Pekerjaan Umum, Kementerian Kesehatan, dan Kementerian Perhubungan.

- Untuk program relokasi pasca bencana merupakan tanggung jawab Kementerian Tenaga Kerja dan Transmigrasi (Nakertrans) bekerja sama dengan pemerintah daerah asal transmigran dan pemerintah daerah tujuan transmigran.

- Perlu peningkatan penelitian ilmu pengetahuan dan teknologi yang terkait dengan program Pengurangan Resiko Bencana dengan pendekatan teknologi tepat guna dengan mempertimbangkan unsur kearifan lokal.

Evaluasi juga dilakukan melalui test untuk mengukur peningkatan kognitifnya. Hasil tes lalu diuji dengan uji beda (uji-t). Hasilnya menunjukkan bahwa pemahaman dan kemampuan siswa berbeda antara sebelum dan sesudah dilakukan kegiatan penelitian.

Evaluasi dan monitoring juga dilakukan pada diskusi mengenai perancangan dan pembelajaran menggunakan perangkat yang dibuat. Setelah itu, hasil kegiatan diskusi dengan mahasiswa KKN-PPL kemudian dilakukan revisi dan penyesuaian dengan tingkat kemampuan siswa. Hasilnya digunakan untuk memberikan saran, masukan, kritikan, dan penyempurnaan pekerjaan. Pada kegiatan ini evaluator dan kolaborator juga mengamati hambatan-hambatan siswa dalam mengembangkan kemampuannya.

Hasil pengukuran kemampuan rendah, maka dievaluasi metoda pembelajarannya, yaitu dengan cara diskusi mengenai materi yang sudah dibahas dan dievaluasi program dan manualnya dengan cara penyempurnaan, yang dilakukan adalah dengan penambahan pembahasan teoretis dan melengkapi referensi. Dengan cara ini siswa terbantu dalam pemahaman konsep dan dapat bertukar fikiran mengenai konsep-konsep yang meragukan atau tidak dapat dipahami.

Hasil kegiatanya tidak baik maka dilakukan perbaikan pada pelaksanaan pembelajaran berikutnya. Perbaikan ini terutama dalam menganalisis hasil output program web, kemampuan interaktifnya, serta pengulangan entry data ketika terdapat kesalahan yang sifatnya teknis, dan lain-lain.

Hasil penelitian tindakan kelas dikelompokkan kedalam dua aspek, yaitu keberhasilan proses dan keberhasilan produk. Keberhasilan proses yang dimaksud dalam penelitian ini adalah proses pembelajaran dengan menggunakan perangkat yang dibuat (science equipment) dengan mengamati perkembangan kemampuan kognitif dan kinerja siswa pada setiap kegiatan. Proses pelaksanaan kegiatan dapat dilihat pada rekaman foto yang disertakan bersama laporan ini. Adapun keberhasilan produk ditandai dengan telah dapat dibuatnya perangkat, pelaksanaan kegiatan pembelajaran, laporan kegiatan praktik dan diskusi, hasil tes kognitif dan performance.

\section{Keberhasilan Proses}

Keberhasilan proses dalam penelitian ini meliputi tiga hal yaitu keberhasilan proses dalam pemahaman materi Sains, keberhasilan proses dalam melakukan kegiatan pembelajaran (kinerja), dan keberhasilan proses dalam melakukan kegiatan praktikum yang ditandai dengan kemampuan membuat laporan dan diskusi. Proses pemahaman konsep ditandai dengan frekuensi diskusi dalam kelompok dan catatan kolaborator. 
Frekuensi diskusi kelompok terungkap berdasarkan identifikasi awal sebelum diadakan tindakan dengan cara studi kilas balik, yaitu jarang dilakukan diskusi mengenai program melalui proses pembelajaran yang diadakan. Setelah diadakan tindakan, frekuensi diskusi menjadi rata-rata tiga kali, yaitu sebelum kegiatan, ketika sedang berlangsung kegiatan, dan setelah pelaksanaan kegiatan. Peningkatan frekuensi diskusi ini membantu siswa dalam memahami konsep Sains. Proses catatan kolaborator, sebelum dan sesudah adanya kegiatan jelas terdapat perbedaan karena siswa sebelum melakukan kegiatan tidak menggunakan magang.

\section{Keberhasilan Produk}

Indikator keberhasilan produk ditandai dengan (1) kemampuan mahasiswa KKN - PPL dalam mengajar sains menggunakan perangkat pembelajaran sains bertambah; (2) kemampuan siswa dalam bidang sains meningkat; (3) siswa memiliki kemampuan kognitif, afektif dan psikomotor melalui kegiatan diskusi dan praktikum; dan (4) mahasiswa KKN - PPL mampu mengembangkan pembelajaran dengan menggunakan media alternatif lainnya.

Butir (1) menunjukkan bahwa kemampuan mahasiswa KKN-PPL dalam mengajar sains menggunakan perangkat pembelajaran yang aplikatif bertambah dapat dilihat dari rekaman kegiatan dan diskusi antara kolaborator dengan mahasiswa KKN-PPL yang bersangkutan. Peningkatan kemampuan mahasiswa KKN-PPL ini memang mudah diprediksi karena sebelumnya mahasiswa KKN-PPL tidak melakukan proses pembelajaran menggunakan program ini.

Butir (2) menunjukkan bahwa kemampuan siswa dalam penggunaan media pembelajaran meningkat, indikatornya dapat dilihat dari hasil laporan siswa, diskusi dengan kolaborator dan mahasiswa KKN-PPL, serta data berupa rekaman foto pelaksanaan kegiatan. Kemampuan ini dapat terlihat pula dari kemampuan siswa dalam menganalisis data hasil kegiatan. Pada awalnya siswa belum melakukan diskusi dan praktikum, tetapi setelah kegiatan ini siswa mendapatkan pengalaman mengikuti proses kegiatan.
Butir (3) menunjukkan bahwa siswa memiliki kemampuan kognitif, afektif dan psikomotor melalui kegiatan diskusi dan praktik lapangan, pada dasarnya memiliki indikator yang sama dengan butir (2) di atas. Pada butir (4), mahasiswa KKN-PPL mampu mengembangkan pembelajaran dengan menggunakan media alternatif lainnya, indikatornya dapat dilihat dari hasil wawancara, diskusi dan kolaborasi antara peneliti dan mahasiswa KKN - PPL.

Evaluasi dan monitoring dilakukan pada diskusi mengenai perancangan dan pembelajaran menggunakan perangkat yang dibuat. Setelah itu, hasil kegiatan diskusi dengan mahasiswa KKN-PPL kemudian dilakukan revisi dan penyesuaian dengan tingkat kemampuan siswa . Hasilnya digunakan untuk memberikan saran, masukan, kritikan, dan penyempurnaan pekerjaan. Pada kegiatan ini evaluator dan kolaborator juga mengamati hambatan-hambatan siswa dalam mengembangkan kemampuannya.

Hasil pengukuran kemampuan rendah, maka dievaluasi metoda pembelajarannya, yaitu dengan cara diskusi mengenai materi yang sudah dibahas dan dievaluasi program dan manualnya dengan cara penyempurnaan, yang dilakukan adalah dengan penambahan pembahasan teoretis dan melengkapi referensi. Dengan cara ini siswa terbantu dalam pemahaman konsep dan dapat bertukar fikiran mengenai konsep-konsep yang meragukan atau tidak dapat dipahami.

Pada hasil kegiatan yang tidak baik dilakukan perbaikan pelaksanaan pembelajaran berikutnya. Perbaikan ini terutama dalam menganalisis hasil output program web, kemampuan interaktifnya, serta pengulangan entry data ketika terdapat kesalahan yang sifatnya teknis, dan lain-lain.

Penyajian hasil penelitian tindakan kelas ini dikelompokkan kedalam dua aspek, yaitu: keberhasilan proses dan keberhasilan produk. Keberhasilan proses yang dimaksud dalam penelitian ini adalah proses pembelajaran dengan menggunakan perangkat yang dibuat (science equipment) dengan mengamati perkembangan kemampuan kognitif dan kinerja siswa pada setiap kegiatan. Proses pelaksanaan kegiatan 
dapat dilihat pada rekaman foto yang disertakan bersama laporan ini. Adapun keberhasilan produk ditandai dengan telah dapat dibuatnya perangkat, pelaksanaan kegiatan pembelajaran, laporan kegiatan praktik dan diskusi, hasil tes kognitif dan performance.

\section{PENUTUP}

Penelitian ini sampai pada kesimpulan sebagai berikut. (1) Perangkat pembelajaran berhasil dikembangkan oleh masyarakat terdampak erupsi Merapi dan mendukung kualitas proses dan kualitas hasil belajar mengajar sains.

(2) Guru pengampu mampu melakukan keseluruhan aspek dalam sintaks pembelajaran seperti yang telah dirancang bersama dengan tim peneliti. (3) Aktivitas guru didominasi dengan kegiatan mengelola KBM sesuai dengan rancangan penelitian, mendorong atau melatihkan siswa kemandirian aktif. (4) Akitivitas siswa didominasi dengan kegiatan menggunakan perangkat pembelajaran, praktik lapangan, dan diskusi yang relevan, dan aktivitas berlatih melakukan kemandirian aktif. (5) Kemandirian aktif yang dominan dilakukan oleh siswa adalah keterampilan melakukan pengamatan dan berbagi tugas dalam kelompok untuk menyelesaikan tugas-tugas kelompok. (6) Pada umumnya siswa menyatakan senang dan baru terhadap perangkat pembelajaran dan model pembelajaran yang telah dikembangkan oleh peneliti sehingga siswa berminat untuk mengikuti pembelajaran sains berikutnya seperti yang telah mereka ikuti. (7) Proses belajar mengajar yang menerapkan perangkat pembelajaran dengan perangkat pembelajaran yang dibuat pemulung dapat meningkatkan proporsi jawaban benar siswa.

\section{UCAPAN TERIMA KASIH}

Penelitian ini terlaksana berkat dukungan dana dari Direktorat Penelitian dan Pengabdian Pada Masyarakat, Direktorat Jendral Pendidikan Tinggi, Kementrian Pendidikan dan Kebudayaan melalui penelitian Hibah Bersaing dengan nomor sub kontrak 31/HB-Multitahun/UN 34. 21/2013.

\section{DAFTAR PUSTAKA}

Cennamo,K \& Kalk, D. 2005. Real Word Instructional Design. www. Amazon. com. Diambil tanggal 3 September 2013.

Djajadiningrat S,T. 2008. Membangun Tanpa Merusak Lingkungan. Jakarta: Kantor Menteri Negara Kependudukan dan Lingkungan Hidup.

Drajat. 2011. "Arti Penting Pendidikan Mitigasi Bencana dalam Mengurangi Resiko Bencana". Cakrawala Pendidikan, Juni 2011, Th. XXX, No. 2.

Gay. 1990. The Condition of Learning and Theory of Instruction. 4 th Edition. New York: Holt Rinehart, and Winston.

Gelbert, M.2005. Environmental Management focusing on Solid Waste Management - a Script and Reader. New York: Dietikon.

Kemp, J.E., G.R. Morisson, \& Steven M. R. 2004. Designing Effective Instruction. New York: Macmillan College Publishing Company.

Murtado, Djuli dan Sa'id, E. Gumbira. 2008. Limbah Padat. Jakarta: Mediyatama Sarana Perkasa.

PPPGT/VEDC Malang. 2006. Methodological Chart Ruang Lingkup Materi. Malang: VEDC. 